\title{
EVALUATING THE COMPETITIVE ABILITY OF POTATO CULTIVARS WITH WEEDS
}

\author{
NOUROLlahi, F. ${ }^{1}$ - MoHAmmadDOUST-ChAMANABAD, H. R. ${ }^{1 *}$ - HASSANPANAH, D. ${ }^{2}-$ \\ ANVAR, M. ${ }^{1}$ \\ ${ }^{1}$ Department of Agronomy and Plant Breeding, Faculty of Agriculture and Natural Resources \\ University of Mohaghegh Ardabili, Ardabil, Iran
}

${ }^{2}$ Ardabil Agriculture and Natural Resources Research Center, Ardabil, Iran

*Corresponding author

e-mail:hr_chamanabad@yahoo.com; phone: +98-915-108-2239

(Received 12 $2^{\text {th }}$ Mar 2019; accepted 22 $2^{\text {nd }}$ May 2019)

\begin{abstract}
Using competitive cultivars can be an important integrated weed management (IWM) tool in sustainable agricultural systems and in cultivation of healthy products. Differential competitive ability of 10 potato cultivars was examined in 2015 and 2016 in the research field of the University of Mohaghegh Ardabili, Ardabil, Iran. Experiment was established using a randomized complete block design with three replications. 10 potato cultivars (Caesar, Kennebec, Banba, Markies, Hermes, Marfona, 397097-14, Difla, Satina, Natascha) were observed that has grown with and without natural weed flora. Potato cultivars differed in ability to reduce weed density and weed biomass. In weed conditions, tuber yield ranged from 19.27 in Hermes to $55.56 \mathrm{t} \mathrm{ha}^{-1}$ in Satina. Also yield loss ranged from 0 to $38.93 \%$. Satina cultivar had the highest competitive index $(\mathrm{CI})$ and could reduce the weed dry mass by 2 to 3 times more than Hermes as a poor cultivar. In general, the results of this study declare that Satina cultivar was considered as competitive and recommended more for cultivation in Ardabil region than other cultivars. It is more stable than weed, and could have greatly reduce the density and biomass of weed.
\end{abstract}

Keywords: competitive ability, potato, healthy hazards, integrated weed management, sustainable agriculture, weed interference

\section{Introduction}

Besides cereal, potato, Solanum tuberosum L., is an important crop in the world. Iran has the $13^{\text {th }}$ place in potato production (FAO Statistic, 2016). Potato is the most important crop in the Ardabil area. Ardabil contains 23000 ha of arable land, of which 18500 ha was used for potato production in Iran in 2017, with an average yield of $23.7 \mathrm{t} \mathrm{ha}^{-1}$ (IRANSTAT, 2017), but weeds are the main barrier to potato production. Yield loss in potato due to weed interference has been reported 20-30\% in Iran (Khalghani, 2010). Few herbicides and modes of action are usually available for use in potato cultivations, so the risk of developing herbicide-resistant weed populations can increase. On the other hand, weed control is one of the main limitations in sustainable agriculture. Efficient weed management is essential for successful organic crop protection, and finding crop cultivars that confer a high degree of competitive ability against weeds are highly desirable (Mason et al., 2006). Although competitiveness has not traditionally been considered a priority for breeding or farmer cultivar choice the challenge of managing herbicide- resistant weed populations, environmental concerns and the unmet needs of organic producers and smallholder farmers has, however, renewed interest in cultural weed control options, including competitive cultivars (Worthington and Rebery-Horton, 2013; Andrew et al., 2015). Many research in cereals have examined how cultivar selection may be used as a mean of weed control by choosing cultivars that are inherently more competitive with, or more tolerant of, commonly 
encountered or key weed species (Korres and Froud-Williams, 2002; Worthington and Rebery-Horton, 2013; Lemrele, 2015; Abdollahi and Mohammaddust-Chamanabad, 2017). Some findings presented in complement agronomic and physiological studies of crop- weed interactions in other species such as soybean (Vollman et al., 2010), potato (Nelson and Thoreson, 1981; Love et al., 1995; Khalegi et al., 2007; Colquhoun et al., 2009; Hutchinson et al., 2011; Bashiri-Majd, 2015), tomato (Gonzales-Ponce et al., 1996), canola (Hashem et al., 2010), field pea (Jacob et al., 2016).

There are two aspects of cultivar competitive ability; the ability to compete with weed, is expressed as competitive index (CI) and the ability to tolerate weed interference, is expressed as weed interference tolerance index (WITI). A competitive cultivar (high CI) can maintain high yield in the presence of weeds and can reduce weed biomass or seed production (Tilman, 1987; Goldberg, 1990), while tolerant cultivars only maintain high yield in the presence of weeds. Suppressing weeds is beneficial for weed management in future growing seasons while tolerating weeds is only beneficial in the current growing season. However, the relationship between aspects has not been addressed in potato. According to Cory et al. (2016) it has been reported that pea cultivars that are ranked the highest for AWC were associated with lower weed fecundity, whereas the highest-yielding cultivars generally were those that had the highest CI variation in competitive ability of wheat cultivars (Blackshow, 1994; Lemerle et al., 2001; Mohammaddust-Chamanabad et al., 2014). Abdollahi and Mohammaddust-Chamanabad (2017) also reported positive relationship between the yield of wheat and WITI similarly with CI. Colquhoun (2009) observed that differences in yield among cultivars grown in the presence of weeds suggest differential tolerance of weed competition ability, however, the ability to suppress weeds was similar among cultivars. Khaleghi et al. (2007) reported significant differences among potato cultivars in tolerance of weed presence. According to Bashiri-Majd (2015) late potato cultivars had high competitive ability that produced more yield and reduced weed biomass.

Many long-term studies still conduce on determining cultivars resistance to disease and good combination of traits for logical conditions. While the evaluation of crop cultivars based on competitive ability is necessary. Large genotype by environment interactions may cause difficulties in selecting for competitiveness (Coleman et al., 2001) and selection for competitiveness could be at the expense of other important criteria (Brennan et al., 2001). Nevertheless, within a given climatic zone there appears to be sufficient genetic variation in crop competitive ability (Acciaresi et al., 2001; Coleman et al., 2001) for such selection to be introduced into breeding programs. The over goal of this study was to (1) evaluate the ability potato cultivars to suppress weed density and biomass, (2) rank these cultivars based on competitive ability index, and (3) compare the ability of the same cultivars to maintain tuber yield in the presence of weeds.

\section{Materials and methods}

The study was conducted at the Agricultural Research Farm of the University of Mohaghegh Ardabili, Ardabil, Northwestern Iran (longitude $48^{\circ} 18^{\prime} \mathrm{E}$, latitude $38^{\circ} 15^{\prime} \mathrm{N}$, $1338 \mathrm{~m}$ above sea level) in 2015 and 2016 on loamy clay soil with $1.57 \%$ organic matter, and $7.8 \mathrm{pH}, \mathrm{EC} 1008 \mu \mathrm{S} \mathrm{cm}^{-1}$. The monthly average air temperatures and total rainfall and long-term averages (1976 to 2014) during the growing season are summarized in Table 1. Air temperature and precipitation was different between years compared with the long-term average data. Compared with the long-term averages, air temperatures were 
lower during both study years. In 2016, rainfall was generally higher during the studied growing season (May to September) compared to the long-term average in 2015, except for lower precipitation in August.

In both years, treatments were arranged in a randomized complete block design, with three replicates. Ten potato cultivars (Caesar, Kennebek, Banba, Markies, Hermes, Marfona, Difla, Satina and one advanced clone, 397007-14) were grown with and without weed interference. The selections were chosen, based on their differing growth attributes (Table 2).

Table 1. Air temperature and rainfall for 2015 and 2016 growing seasons and Long-term averages (1976-2014) at Ardabil, Iran

\begin{tabular}{c|c|c|c|c|c|c}
\hline \multirow{2}{*}{ Month } & \multicolumn{3}{|c|}{ Mean Temperature $\left({ }^{\circ} \mathbf{C}\right)$} & \multicolumn{3}{c|}{ Rainfall (mm) } \\
\cline { 2 - 7 } & Long term & $\mathbf{2 0 1 5}$ & $\mathbf{2 0 1 6}$ & Long term & $\mathbf{2 0 1 5}$ & $\mathbf{2 0 1 6}$ \\
\hline May & 14.8 & 8 & 7.5 & 34.3 & 35.7 & 59.6 \\
June & 18.8 & 12.9 & 15 & 48.6 & 27.7 & 29.7 \\
July & 22.8 & 17.9 & 17 & 26.8 & 7 & 14.2 \\
August & 26 & 19.9 & 19.6 & 8.1 & 3.6 & 0.1 \\
September & 25.5 & 20.4 & 19.8 & 5.1 & 0 & 1.2 \\
October & 23.5 & 16.9 & 18.5 & 10.4 & 48.9 & 6.4 \\
November & 19.3 & 13.3 & 12.2 & 25.3 & 58.3 & 4.8 \\
December & 13.3 & 7.6 & 7.1 & 37.5 & 46.6 & 40.3 \\
January & 7.2 & 2.5 & -1 & 24.9 & 13.9 & 15.4 \\
February & 3.9 & 3.4 & 0.4 & 20.5 & 6.4 & 3.4 \\
March & 4 & 0.4 & 7.5 & 21.3 & 24.9 & 1.2 \\
\hline
\end{tabular}

Plots measured 5 by $4.2 \mathrm{~m}$, including 7 potato rows on $60 \mathrm{~cm}$ row spacing. Potato seed pieces were hand-planted with 7.5 plants $\mathrm{m}^{-2}$ density on May 1, 2015, and 16 May 2016. After the potato emergence, each plot was divided into two equal parts and in one half all weeds were hand-removed during the growing season as weed free plots. Fertilizer was applied at planting $\left(75,150,75 \mathrm{~kg} \mathrm{ha}^{-1} \mathrm{NPK}\right)$ and at tuber initiation $\left(75 \mathrm{~kg} \mathrm{~N} \mathrm{ha}^{-1}\right)$. Supplemental overhead irrigation was supplied to meet crop water demands. Furrow irrigation during the growing season was carried out at the rate of $6000 \mathrm{~m}^{3} \mathrm{ha}^{-1}$ and 10 days.

Data collection included weed density and biomass at end of the season in the weedy plots and tuber yield in all plots. At the end of the season before tuber harvest, weeds were collected from two $0.5 \times 0.6 \mathrm{~m}$ quadrates in each weedy plots. Weeds were counted, dried at $75^{\circ} \mathrm{C}$ for 48 hours and weighed. Potato tuber yield was quantified at season-end by harvesting the three rows in each plot. The following Equations (Eqs.1 and 2) were used for the evaluation of the competitive ability (CI) and tolerance ability (WITI) of potato cultivars (Mohammaddust-Chamanabad, 2011).

$$
W I T I=\frac{(Y p)(Y S)}{(\bar{Y} p)^{2}}
$$

where $\mathrm{Yp}$ is each cultivar yield from the weed free plot, Ys is each cultivar yield from weedy plot. $\bar{Y}$ p mean is the average yield of all potato cultivars from the weed free plot. 
Table 2. Traits of potato cultivars used in this study (ECPD, AHDB and PPA 2018)

\begin{tabular}{|c|c|c|c|c|c|c|c|c|c|c|c|c|c|}
\hline \multirow{3}{*}{ S.No. } & \multirow{3}{*}{$\begin{array}{l}\text { Popular } \\
\text { name }\end{array}$} & \multirow{3}{*}{$\begin{array}{l}\text { Developing } \\
\text { center }\end{array}$} & \multirow{3}{*}{ Parentage } & \multirow{3}{*}{$\begin{array}{l}\text { Year of } \\
\text { released }\end{array}$} & \multicolumn{9}{|c|}{ Characteristics } \\
\hline & & & & & \multicolumn{4}{|c|}{ Tuber } & \multicolumn{5}{|c|}{ Botanical Description } \\
\hline & & & & & Shape & $\begin{array}{c}\begin{array}{c}\text { Color of } \\
\text { skin }\end{array} \\
\end{array}$ & $\begin{array}{c}\text { Color of } \\
\text { flesh }\end{array}$ & $\begin{array}{l}\text { Depth of } \\
\text { eyes }\end{array}$ & Maturity & Height* & \begin{tabular}{|c|}
$\begin{array}{c}\text { Foliage } \\
\text { development }\end{array}$ \\
\end{tabular} & \begin{tabular}{|c|}
$\begin{array}{c}\text { Color of } \\
\text { flower }\end{array}$ \\
\end{tabular} & $\begin{array}{c}\text { Yield } \\
\text { potential }^{* * *}\end{array}$ \\
\hline 1 & Banba & \begin{tabular}{|c|} 
Irish Potato \\
Marketing Ltd
\end{tabular} & Slaney ${ }_{x}$ Estima & 2001 & $\begin{array}{l}\text { Oval- } \\
\text { long }\end{array}$ & Yellow & $\begin{array}{l}\text { Light } \\
\text { yellow }\end{array}$ & Shallow & Early & $\begin{array}{c}\text { Medium- } \\
\text { tall }\end{array}$ & Fairly good & White & Very high \\
\hline 2 & Caesar & $\begin{array}{c}\text { HZPC UK } \\
\text { Limited }\end{array}$ & Monalisax $_{x} R_{\text {RopB1178 }}$ & 1990 & $\begin{array}{l}\text { Oval- } \\
\text { long }\end{array}$ & $\begin{array}{l}\text { White to } \\
\text { yellow }\end{array}$ & Yellow & $\begin{array}{c}\text { Very } \\
\text { shallow- } \\
\text { shallow }\end{array}$ & Intermediate & Medium & Dense & White & Very high \\
\hline 3 & Difla & $\begin{array}{l}\text { Germicopa- } \\
\text { France }\end{array}$ & Sylvia $_{x}$ cara & 1992 & Oval & Yellow & White & $\begin{array}{l}\text { Shallow- } \\
\text { medium }\end{array}$ & Medium late & Tall & Very good & White & Very high \\
\hline 4 & Hermes & $\begin{array}{l}\text { GB seed } \\
\text { industry }\end{array}$ & DD 5158 SW 163/55 & 1973 & $\begin{array}{c}\text { Round- } \\
\text { oval }\end{array}$ & Yellow & $\begin{array}{l}\text { Fairly } \\
\text { yellow }\end{array}$ & $\begin{array}{l}\text { Moderately } \\
\text { deep }\end{array}$ & $\begin{array}{c}\text { Medium early } \\
\text { to medium } \\
\text { late }\end{array}$ & $\begin{array}{c}\text { Medium } \\
\text { to tall }\end{array}$ & Fairly good & Red violet & High \\
\hline 5 & Kennebek & USDA & $\begin{array}{c}\left(\left(\text { Chippewa }{ }_{x} \text { Katahdin }\right)_{x}(3895-\right. \\
\left.\left.13_{x} \text { earlaine }\right)\right)\end{array}$ & 1941 & $\begin{array}{c}\text { Round- } \\
\text { oval }\end{array}$ & $\begin{array}{l}\text { Pale } \\
\text { yellow }\end{array}$ & White & Shallow & $\begin{array}{c}\text { Medium early } \\
\text { to medium } \\
\text { late }\end{array}$ & $\begin{array}{c}\text { Medium } \\
\text { to tall }\end{array}$ & Good & White & High \\
\hline 6 & Markies & Agrico UK ltd & Agria $_{x}$ Fianna & 1984 & $\begin{array}{c}\text { Oval to } \\
\text { long oval }\end{array}$ & Yellow & $\begin{array}{c}\text { Pale } \\
\text { yellow }\end{array}$ & Shallow & $\begin{array}{c}\text { Late to very } \\
\text { late }\end{array}$ & Tall & $\begin{array}{c}\text { Very good to } \\
\text { good }\end{array}$ & White & High \\
\hline 7 & Marfona & Agrico UK ltd & Primora $_{x} K_{051-123}$ & 1975 & $\begin{array}{c}\text { Round- } \\
\text { oval }\end{array}$ & Yellow & $\begin{array}{l}\text { Pale } \\
\text { yellow }\end{array}$ & $\begin{array}{l}\text { Rather } \\
\text { shallow }\end{array}$ & $\begin{array}{c}\text { Medium early } \\
\text { to medium } \\
\text { late }\end{array}$ & Tall & Good & White & $\begin{array}{l}\text { Very } \\
\text { high }\end{array}$ \\
\hline 8 & Natascha & $\begin{array}{l}\text { Marabel }{ }_{x} 91- \\
050-4\end{array}$ & CO.KG,Gmbh & 1998 & Oval & Yellow & $\begin{array}{l}\text { Deep } \\
\text { yellow }\end{array}$ & Shallow & Early & Tall & Good & White & High \\
\hline 9 & Satina & \begin{tabular}{|c|} 
Canadian Food \\
Inspection \\
Agency
\end{tabular} & Puntila $_{x} \mathrm{H} 99 / 73$ & 1971 & $\begin{array}{c}\text { Round } \\
\text { oval-oval }\end{array}$ & Yellow & Yellow & Shallow & Medium early & Tall & $\begin{array}{l}\text { Rapid- } \\
\text { medium }\end{array}$ & White & Very high \\
\hline 10 & $397097-14$ & CIP & 397009 & - & $\begin{array}{c}\text { Round- } \\
\text { oval }\end{array}$ & Yellow & Yellow & Shallow & Intermediate & Tall & Medium & White & High \\
\hline
\end{tabular}

* Medium (60-70 cm), medium to tall $(70-100 \mathrm{~cm})$, Tall $(100-150 \mathrm{~cm}), * *$ High $\left(40-50 \mathrm{t} \mathrm{ha}^{-1}\right)$, very high $\left(\geq 50 \mathrm{t} \mathrm{ha}^{-1}\right)$ 


$$
C I=\left(\frac{V i}{\bar{V}}\right) /\left(\frac{D i}{\bar{D}}\right)
$$

where $\mathrm{Vi}$ is each cultivar yield from the weedy plot, $\bar{V}$ is the average yield of all potato cultivars from the weedy plot. $D_{i}$ is weed dry biomass in each potato cultivar and $\bar{D}$ is average weed dry biomass from weedy plots. Relative Yield Loss was calculated as (Eq.3):

$$
\% \text { Relative Yield Loss }=100(\text { Yweed free }- \text { Yweedy }) /(\text { Yweed free })(\text { Eq.3) }
$$

Data were subjected to ANOVA, normality was checked using the graphical method in Statistical Package for the Social Sciences (SPSS). Means were separated by Duncan multiple rang test $(\mathrm{P} \leq 0.05)$. Interaction between treatment and years, as well as between cultivars and weed competition levels were observed for several parameters; therefor, results are presented by year.

\section{Results}

\section{Weed density and biomass}

The dominant weed species in both years were Turnipweed (Rapistrum rogosum L.), Bindweed (Convolvulus arvensis L.), common lambsquarters (Chenopodium album L.) and red root pigweed (Amaranthus retroflexus L.). The cultivars effect was significant for weed density and weed biomass in both years (Table 3).

\begin{tabular}{|c|c|c|c|c|}
\hline \multirow{3}{*}{ Source of variation } & \multicolumn{4}{|c|}{ Mean Square (MS) values } \\
\hline & \multicolumn{2}{|c|}{2015} & \multicolumn{2}{|c|}{2016} \\
\hline & \multicolumn{2}{|c|}{ Weed density } & \multicolumn{2}{|c|}{ Weed biomass } \\
\hline Cultivar & $94^{* *} \cdot 3136$ & $4484.41 *$ & $11^{* *} .154127$ & ${ }^{* * *} 02.10030$ \\
\hline Error & 867.30 & 3257.01 & 23772.97 & 3657.48 \\
\hline C.V. $(\%)$ & 43.93 & 44.71 & 2.58 & 30.74 \\
\hline
\end{tabular}

Table 3. ANOVA for the effect of potato cultivar on weed density and weed biomass

$* * *$ significant at the $\mathrm{p} \leq 0.01$ and $\mathrm{p} \leq 0.05$, respectively

Results showed that weed density ranged from 15.6 to 128.9 plant $\mathrm{m}^{-2}$ in both years depending on potato cultivar. In both years Satina and Natascha cultivars had the lowest

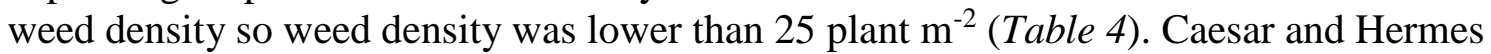
cultivar had the highest weed density. Weed biomass ranged from a minimum of 224.38 for Satina to a maximum of 998.96 for Caesar (Table 4). Natascha had consistently a minimum value for weed density in both years. Some cultivars differed substantially in weed biomass among years. For example, Satina, Natascha and Banba had higher ranking in 2015 compared to 2016. Kennebek, Satina, Markies and 397097-14 had higher ranking for weed biomass in 2016 compared to 2015. Results showed that in 2016, all cultivars significantly had less weed biomass. So this may be due to more rainfall in 2016. Regarding the average throughout both year, the highest and the lowest weed biomass was observed in Caesar and Satina cultivars, respectively (Table 4). 
Table 4. Potato cultivar weed density and weed biomass in 2015 and 2016

\begin{tabular}{|c|c|c|c|c|c|c|}
\hline \multirow{2}{*}{ Cultivar } & \multicolumn{3}{|c|}{$\begin{array}{c}\text { Weed density } \\
\left(\text { plant } / \mathbf{m}^{2}\right)\end{array}$} & \multicolumn{3}{|c|}{$\begin{array}{c}\text { Weed biomass } \\
\left(\mathrm{gm}^{-2}\right)\end{array}$} \\
\hline & 2015 & 2016 & Mean & 2015 & 2016 & Mean \\
\hline Caesar & $101.0^{\mathrm{f}}$ & $98.7^{c}$ & 99.85 & $998.96^{\mathrm{g}}$ & $210.10^{b c}$ & 604.5 \\
\hline Kennebek & $70.8^{\text {def }}$ & $84.7^{\mathrm{ab}}$ & 77.75 & $738.44^{\mathrm{fg}}$ & $128.00^{\mathrm{a}}$ & 433 \\
\hline Banba & $61.4^{\mathrm{abc}}$ & $88.9^{\mathrm{ab}}$ & 75.15 & $398.02^{a b}$ & $205.64^{b c}$ & 302 \\
\hline Markies & $89.6^{\text {ef }}$ & $82.2^{\mathrm{ab}}$ & 85.9 & $537.81^{\text {ef }}$ & $147.38^{\mathrm{a}}$ & 343 \\
\hline Hermes & $102.1^{\mathrm{f}}$ & $128.9^{\mathrm{c}}$ & 115.5 & $741.25^{\mathrm{fg}}$ & $271.51^{\mathrm{c}}$ & 506.5 \\
\hline Marfona & $85.4^{\text {ef }}$ & $106.2^{\mathrm{c}}$ & 95.8 & $457.60^{\mathrm{abc}}$ & $222.22^{b c}$ & 340 \\
\hline $397097-14$ & $87.5^{\text {ef }}$ & $84.9^{\mathrm{ab}}$ & 82.2 & $492.50^{\mathrm{def}}$ & $150.09^{\mathrm{a}}$ & 321.5 \\
\hline Difla & $34.9^{\mathrm{ab}}$ & $76.9^{\mathrm{ab}}$ & 55.9 & $472.76^{\mathrm{def}}$ & $302.04^{\mathrm{c}}$ & 387 \\
\hline Satina & $21.9^{\mathrm{a}}$ & $22.3^{\mathrm{a}}$ & 22.1 & $224.38^{\mathrm{a}}$ & $140.89^{\mathrm{a}}$ & 182.6 \\
\hline Natascha & $15.6^{\mathrm{a}}$ & $26.3^{\mathrm{a}}$ & 20.95 & $343.75^{a b}$ & $189.96^{b c}$ & 304 \\
\hline
\end{tabular}

In each column, means followed by the same letter do not differ significantly according to a Duncan test performed at $\mathrm{p} \leq 0.05$

\section{Potato yield and yield loss}

The cultivars effect was significant for potato yield in both years, except for yield in weed free plots in 2015 (Table 5). In weed free plots, tuber yield ranged from $29.58 \mathrm{t} \mathrm{ha}^{-1}$ for Kennebek cultivar to $57.06 \mathrm{t} \mathrm{ha}^{-1}$ for Satina cultivar in 2015 compared with $24.44 \mathrm{t} \mathrm{ha}^{-1}$ for Difla cultivar to $38.64 \mathrm{t} \mathrm{ha}^{-1}$ for Satina cultivar in 2016 (Table 6).

Table 5. ANOVA for the effect of potato cultivar on yield and competition indices

\begin{tabular}{c|c|c|c|c|c|c|c|c}
\hline \multirow{2}{*}{$\begin{array}{c}\text { Source of } \\
\text { variation }\end{array}$} & \multicolumn{4}{|c|}{$\mathbf{2 0 1 5}$} & \multicolumn{4}{c}{$\mathbf{2 0 1 6}$} \\
\cline { 2 - 9 } & $\begin{array}{c}\text { Yield } \\
\text { weed free }\end{array}$ & $\begin{array}{c}\text { Yield } \\
\text { weedy }\end{array}$ & CI & WITI & $\begin{array}{c}\text { Yield } \\
\text { weed free }\end{array}$ & $\begin{array}{c}\text { Yield } \\
\text { weedy }\end{array}$ & CI & WITI \\
\hline Cultivar & $325.730^{\mathrm{ns}}$ & $459.517^{* *}$ & $2.08^{* *}$ & $1.01^{* *}$ & $65.303^{*}$ & $56.930^{*}$ & $0.56^{*}$ & $0.17^{\mathrm{ns}}$ \\
Error & 996.304 & 391.118 & 0.34 & 0.21 & 148.32 & 202.56 & 0.29 & 0.13 \\
\hline C.V. (\%) & 45.40 & 87.28 & 49.77 & 49.25 & 57.17 & 47.18 & 45.63 & 38.22 \\
\hline
\end{tabular}

$* * *$ and ns: significant at the $p \leq 0.01$ and $p \leq 0.05$ and non significant, respectively

In weedy plots, tuber yield ranged from $24.33 \mathrm{t} \mathrm{ha}^{-1}$ for Hermes cultivar to $55.56 \mathrm{t} \mathrm{ha}^{-1}$ for Satina cultivar in 2015 compared with $19.27 \mathrm{tha}^{-1}$ for Hermes cultivar to $34.53 \mathrm{t} \mathrm{ha}^{-1}$ for Satina cultivar in 2016 (Table 6). Satina and 397097-14 cultivars had the highest tuber yield in weedy and weed free plots in both years, so their yield loss was down to $9 \%$. In 2015 year, yield loss of Kennebek cultivar was about zero, but it's yield was low too (Table 6).

\section{Weed competition indices}

The cultivars effect was significant for CI and WITI in both years, except for WITI in 2016 (Table 5). Values for CI ranged from 0.31 to 3.15 in 2015 compared with 0.54 to 
1.88 in 2016. Results showed that Satina had the highest CI in both years followed by 397097-14 cultivar, so in both cultivar weed biomass were lower and tuber yield was more than the rest (Tables 4,6 and 7 ).

Values for WITI ranged from a minimum of 0.36 for Caesar to a maximum of 2.16 for 397097-14 cultivar in 2015. 397097-14 and Satina had higher ranking in this year (Table 7). There were no significant variety for WITI value within cultivars in 2016 (Table 5).

Table 6. Potato cultivar yield in weed-free and weedy condition, relative yield loss in 2015 and 2016

\begin{tabular}{|c|c|c|c|c|c|c|}
\hline \multirow[b]{2}{*}{ Cultivar } & \multicolumn{3}{|c|}{2015} & \multicolumn{3}{|c|}{2016} \\
\hline & $\begin{array}{l}\text { Yield }_{\text {wf }} \\
\left(\text { t ha }^{-1}\right)\end{array}$ & $\begin{array}{r}\text { Yield }_{w} \\
\left(\text { t ha }^{-1}\right)\end{array}$ & $\% \mathrm{YL}$ & $\begin{array}{l}\text { Yield }_{w f} \\
\left(t^{h} \mathbf{h a}^{-1}\right)\end{array}$ & $\begin{array}{r}\text { Yield }_{w} \\
\left(\text { t ha }^{-1}\right)\end{array}$ & $\% \mathrm{YL}$ \\
\hline Caesar & 37.00 & $29.39^{d}$ & 17.74 & $35.86^{\mathrm{ab}}$ & $23.38^{\mathrm{cd}}$ & 27.45 \\
\hline Kennebek & 29.58 & $29.78^{d}$ & 0 & $29.23 \mathrm{abc}$ & $25.31^{\mathrm{ab}}$ & 17.02 \\
\hline Banba & 47.39 & $35.39^{b c}$ & 23.40 & $36.76^{\mathrm{ab}}$ & $25.94^{\mathrm{ab}}$ & 22.48 \\
\hline Markies & 49.72 & $31.06^{\mathrm{c}}$ & 31.42 & $27.47^{\text {ef }}$ & $27.58^{a b}$ & 0.56 \\
\hline Hermes & 44.11 & $24.33^{\mathrm{d}}$ & 38.93 & $28.44^{\mathrm{def}}$ & $19.27^{\mathrm{d}}$ & 18.77 \\
\hline Marfona & 34.44 & $28.00^{\mathrm{d}}$ & 10.01 & $31.03^{a b c}$ & $25.60^{\mathrm{ab}}$ & 6.10 \\
\hline $397097-14$ & 48.06 & $46.00^{\mathrm{a}}$ & 4.29 & $36.73^{\mathrm{ab}}$ & $29.08^{a b}$ & 8.31 \\
\hline Difla & 57.06 & $51.22^{\mathrm{ab}}$ & 10.5 & $24.44^{\mathrm{f}}$ & $22.31^{\mathrm{d}}$ & 8.6 \\
\hline Satina & 55.89 & $55.56^{\mathrm{a}}$ & 0.14 & $38.64^{\mathrm{a}}$ & $34.53^{\mathrm{a}}$ & 0 \\
\hline Natascha & 38.11 & $34.17^{b c}$ & 10.46 & $30.97^{\mathrm{def}}$ & $24.74^{\mathrm{cd}}$ & 5.22 \\
\hline
\end{tabular}

In each column, means followed by the same letter do not differ significantly according to a Duncan test performed at $\mathrm{p}<0.05, \mathrm{p}<0.01$

Table 7. Potato cultivar competition indices in 2015 and 2016

\begin{tabular}{c|c|c|c|c}
\hline \multirow{2}{*}{ Cultivar } & \multicolumn{2}{|c|}{ CI } & \multicolumn{2}{|c}{ WITI } \\
\cline { 2 - 5 } & $\mathbf{2 0 1 5}$ & $\mathbf{2 0 1 6}$ & $\mathbf{2 0 1 5}$ & $\mathbf{2 0 1 6}$ \\
\hline Caesar & $0.31^{\mathrm{g}}$ & $1.12^{\mathrm{abc}}$ & $0.36^{\mathrm{d}}$ & 0.91 \\
Kennebek & $0.62^{\mathrm{efg}}$ & $1.48^{\mathrm{abc}}$ & $0.60^{\mathrm{d}}$ & 0.83 \\
Banba & $1.29^{\mathrm{bcd}}$ & $1.00^{\mathrm{def}}$ & $0.95^{\mathrm{bc}}$ & 1.03 \\
Markies & $0.62^{\mathrm{efg}}$ & $1.38^{\mathrm{abc}}$ & $0.79^{\mathrm{c}}$ & 0.88 \\
Hermes & $0.44^{\mathrm{fg}}$ & $0.54^{\mathrm{f}}$ & $0.52^{\mathrm{d}}$ & 0.66 \\
Marfona & $0.91^{\mathrm{bcd}}$ & $0.83^{\mathrm{ef}}$ & $0.49^{\mathrm{d}}$ & 0.85 \\
397097-14 & $1.59^{\mathrm{b}}$ & $1.67^{\mathrm{ab}}$ & $2.16^{\mathrm{a}}$ & 1.21 \\
Difla & $1.40^{\mathrm{bcd}}$ & $0.68^{\mathrm{ef}}$ & $1.13^{\mathrm{bc}}$ & 0.62 \\
Satina & $3.15^{\mathrm{a}}$ & $1.88^{\mathrm{a}}$ & $1.70^{\mathrm{ab}}$ & 1.43 \\
Natascha & $1.54^{\mathrm{bc}}$ & $1.12^{\mathrm{abc}}$ & $0.66^{\mathrm{c}}$ & 0.93 \\
\hline
\end{tabular}

In each column, means followed by the same letter do not differ significantly according to a Duncan test performed at $\mathrm{p}<0.05, \mathrm{p}<0.01$

To aid in the interpretation of results, potato cultivars were categorized as highly, poorly, and intermediately competitive. Since the lowest weed density, weed biomass, yield loss, and the highest competitive index were recorded in satina in both years (Tables 
6 and 7) this may be considered highly competitive. Casear and Hermes had the highest weed characteristics and yield loss and the lowest competitive index in both years (Tables 4, 6 and 7) thus these may be considered poorly competitive. The rest were not classed as poorly or highly and were considered intermediately competitive (Figures 1 and 2).

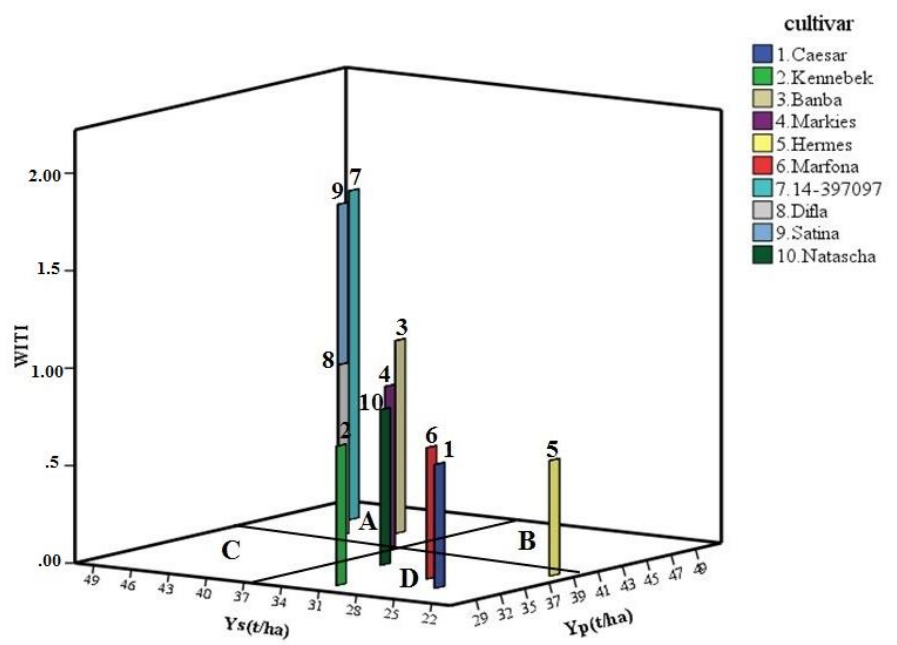

Figure 1. Three dimensional diagram of WITI index for 10 Potato genotypes based on Potato yield $\left(t \mathrm{th}^{-1}\right)$ with weed $\left(Y_{s}\right)$ and without presence of weed $\left(Y_{p}\right)$

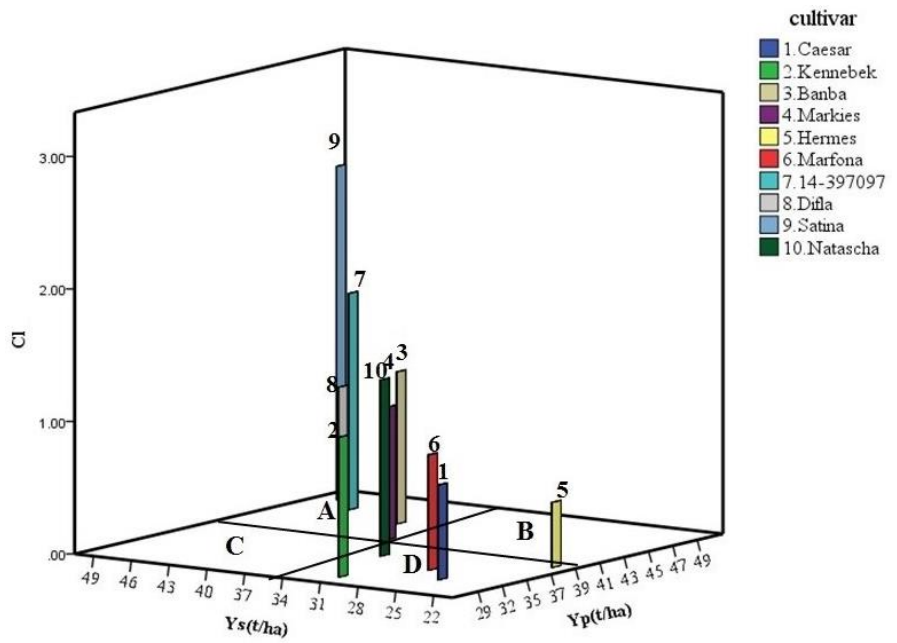

Figure 2. Three dimensional diagram of CI index for 10 Potato genotypes based on Potato yield $\left(t\right.$ ha $\left.{ }^{-1}\right)$ with weed $\left(Y_{s}\right)$ and without presence of weed $\left(Y_{p}\right)$

\section{Discussion}

Cultivar competitiveness can be expressed as the ability of a cultivar to maintain yield when grown in the presence of weed and can be measured by weed interference tolerance index (WITI) or as one that is able to suppress weed growth, which is measured by competitive index (CI) (Watson et al., 2006). These are important in different production systems. For example, WITI is more suitable for conventional production systems, where 
herbicides are used. While in organic systems, CI is important to minimize seed return. However, the relationship between these aspects has not been addressed in potato. In this study, the potato cultivars differed significantly in the suppression weed growth. High CI in Satina caused to reduced weed density and weed biomass and allowed minimizing yield loss. This is in agreement with Watson et al. (2006) who reported barley yield loss and reduced weed seed return when high competitiveness barley cultivars were grown. It has been reported that weed biomass differ through potato cultivars (Nelson and Thoreson, 1981; Love et al., 1995; Khalegi et al., 2007; Hutchinson et al., 2011). Although, Conley et al. (2001) and Colquhoun et al. (2009) reported no differences in weed biomass with six potato cultivars.

Our results showed that Satina cultivar had high CI and, while 397097-14 cultivar had high WITI. Jordan (1993) and Lemerle et al. (2001) stated that CI and WITI might not necessarily be present in the same variety. WITI and CI are traits that differ both genetically and agronomically. CI is often associated with traits including vigorous growth, allelopathic potential, large seedling ground cover, height, canopy structure and overall leaf area (Hansen et al., 2008). 397097-14 is a new cultivar and Satina is an old (released 1971) cultivar. Murphy et al. (2008) reported that modern wheat cultivars were competitiveness than older cultivars. In other words, there is no trade-off among yield and competitive ability.

Potato yield and weed biomass for all cultivars was relatively greater in 2015 than in 2016, this difference between years in weed biomass as well as yield could have been caused by a relatively early rainfall in the seasonal growing conditions in 2015 than in 2016. According to various studies, potato responds to improved moisture conditions (Mazurczyk et al., 2009; Rolbiecki et al., 2009; Zaski, 2011; Karanja et al., 2014).

\section{Conclusion}

Potato cultivar competitive ability has a substantial range and can be an important IWM tool or it can be used in conjunction with other IWM tools such as yield loss thresholds and reduction of herbicide hazards. Satina and 397097-14 had highly competitive abilities and can be used in sustainable systems.

\section{REFERENCES}

[1] Abdollahi, F., Mohammaddust-Chamanabad, H. R. (2017): The Competitive Response Investigation of 18 Wheat (Triticum aestivum L.) Cultivars with Wild Mustard (Sinapis arvensis). - Plant Protection 30: 629-638. DOI: 10.22067/jpp.v30i4.50675.

[2] Acciaresi, H. A., Chidichimo, H. O., Sarondon, S. J. (2001): Traits Related to Competitive Ability of Wheat (Triticum aestivum) Varieties Against Italian Ryegrass (Lolium multiflorum). - Biological Agriculture and Horticulture 19: 275-286. DOI: 10.1080/01448765.2001.9754930.

[3] AHDB. Agriculture and Horticulture Development Board. (2018): Potato Variety Database. - Retrived from http://varieties.ahdb.org.uk/varieties. Accessed on 14.11.2018.

[4] Andrew, I. K. S., Storkey, J., Sparkes, D. L. (2015): A Review of the Potential for Competitive Cereal Cultivars as a Tool in Integrated Weed Management. - Weed Research 55: 239-248. DOI: 10.1111/wre.12137.

[5] Bashiri-Majd, M. (2015): Evaluation of Potato Cultivars Response to Weed Competition. - Master's Thesis, Buali Sina University, Hamedan, Iran. Retrived from http://ganj-oldirandoc.ac.ir/articles/903685. Accesssed on 14.02.2019. 
[6] Blackshaw, R. E. (1994): Differential Competitive Ability of Winter Wheat Cultivars Against Downey Brome. - Agronomy Journal 86: 649-654. DOI: 10.2134/agronj1994.00021962008600040012x.

[7] Brennan, J. P., Lemerle, D., Martin, P. (2001): Economics of Increasing Wheat Competitiveness as a Weed Control Weapon. - Contributed Paper Presented to the $45^{\text {th }}$ annual conference of the Australian Agriculture and Resource Economic Society. Adelaide, 22-25 January 2001, South Australia.

[8] Coleman, R. D., Gill, G. S., Rebetzke, G. J. (2001): Identification of Quantitative Trait Loci for Traits Conferring Weed Competitiveness in Wheat (Triticum aestivum L.). - Australian Journal of Agriculture Research 52: 1235-1246. DOI: 10.1071.ARO1055.

[9] Colquhoun, J. B., Konieczka, Ch. M., Rittmeyer, R. A. (2009): Ability of Potato Cultivars to Tolerate and Suppress Weeds. - Weed Technology 23: 287-291. DOI: 10.1614/WT-08062.1 .

[10] Conley, S., Binning, L., Connell, T. (2001): Effect of Cultivar, Row Spacing, and Weed Management on Weed Biomass, Potato Yield, and Net Crop Value. - American Journl of Potato Research 78: 31-37.

[11] Cory, E. J., Eric, N. J., Miles, F. D., Christian, J. W. (2016): Evaluating the Competitive Ability of Semileafless Field Pea Cultivars. - Journal of Weed Science 64: 137-145. DOI: 10/1614/WS-D-15-0011301.

[12] European Cultivated Potato Database (ECPD) (2018): Varieties. - http://europotato.org. Accessed on 20.03.2019.

[13] FAOSTAT. (2016): Food and Agriculture Organization of the United Nations. - Retrived from http://www.faostat.org.

[14] Goldberg, D. E., Miller, T. E. (1990): Effect of Different Resource Additions on Species Diversity in an Annual Plant Comunity. - Journal of Ecology 71: 213-225.

[15] Gonzales-Ponce, R., Zancada, C., Vardugo, M., Salas, L. (1996): Plan Height as a Factor in Competition Between Black Nightshade and Two Horticultural Crops (Tomato and Pepper). - Horticulture Science 71: 453-460. DOI: 10.1080//1462031.6.1996.11515426.

[16] Hashem, A., Borger, C. P. D., Riethmuller, G. (2010): Weed Suppression by Crop Compete. $-17^{\text {th }}$ Australasian weeds conference. New Zealand, 26-30 September, pp. 6366.

[17] Hutchinson, P. J. S., Beutler, B. R., Fair, J. N. (2011): Hairy Nightshade (solanum sarranchoides) Competition with Two Potato Varietes. - Weed Science 59: 37-42. DOI: 10.1614/ws-d-10.00003.1.

[18] IRANSTAT. (2017): Startisical Center of Iran. - Retrieved from http://www.amar.org.ir. Accessed on 25.10.2018.

[19] Jacob, C. E., Johnson, E. N., Dyck, F. D., Willenborg, Ch. J. (2016): Evaluating the competive ability of smile a fless field pea cultivars. - Weed Science 46: 137-145. DOI: 10.1614/WS-D-15-00113.1.

[20] Karanja, A. M., Shasanya, Ch., Makokha, G. (2014): Analysis of Rainfall Variability on Potato Production in Kenya: A Case of Oljoro-orok Division. - Asian Journal of Applied Sciences 2: 447-456.

[21] Khalegi, F., Hejazi, A., Zand, E., Allahdadi, I., Jahedi, A. (2007): Evaluating the Competitive Ability of Potato Cultivars with Weeds. - Applied Entomobgy and Phytopathology journal 75: 95-108.

[22] Khalgani, J. (2010): Research Strategic Plan for Weed Management. - Iranian Research Institute of Plan Protection. Tehran, pp. 331-362.

[23] Korres, N. E., Froud-Williams, R. J. (2002): Effects of Winter Wheat Cultivars and Seed Rate on the Biological Characteristics of Naturally Occurring Weed Flora. - Weed Research 42: 417-428.

[24] Lemerle, D., Gill, G. S., Murphy, C. E., Walker, S. R. (2001): Genetic Improvement and Agronomy for Enhanced Wheat Competitiveness with Weeds. - Australian Journal of Agriculture Research 52: 527-548. DOI: 10 .1071/AR01056. 
[25] Lemerle, D., Verbeek, B., Orchard, B. (2015): Ranking the Ability of Wheat Varieties to Complete with Lolium rigidum. - Journal Weed Research 41: 197-209. DOI: 10.1046/j.1365-3180.2001.00232.X.

[26] Love, S. L., Eberlein, C. V., Sturk, J. C., Bohi, W. L. (1995): Cultivar and Seed Piece Spacing Effects on Potato Compitiveness with Weeds. - American Potato Journal 72: 197209. DOI: $10.1007 / \mathrm{BF} 02855036$.

[27] Mason, H., Goonewardence, L., Spaner, D. (2008): Competitive Triats and the Stability of Wheat Cultivators in Differing Natural Weed Environment on the Northern Canadian Prairies. - Agriculture Science 146: 21-33. DOI: 10.1017/S0021859607007319.

[28] Mazurczyk, W., Wierzbicka, A., Wroniak, J. (2009): Influence of Optimisation of Irrigation and Nitrogen Fertilisation on some Growth Parameters and Yield of Early Potato Variety. - Infrastructure and Ecology of Rural Areas 3: 91-100. (in Polish).

[29] Mohammaddoust-Chamanabad, H. R. (2011): Introduction to Scientific and Practical Principle of Weed Control. - The Ardabil University Jihad Publications, Ardabil.

[30] Mohammaddust-Chamanabad, H. R., Bakhshi, M., Mohammadnia, S. H. (2014): Evaluation of Weed Tolerace and Competition Indices of Wheat Genotypes. - Iranian Journal of Weed Science 10: 155-166.

[31] Murphy, K. M., Dawson, J. C., Jones, S. S. (2008): Relationship Among Phenotypic Growth Traits, Yield and Weed Suppression in Spring Wheat Landraces and Modern Cultivars. - Field Crops Research 105: 107-115. DOI: 10.1016/j.fcr.2007.08.004.

[32] Nelson, D. C., Thoreson, M. C. (1981): Competition Between Potatoes (Solanum Tuberosum) and Weeds. - Weed Science 29: 672-677. DOI: 10.1017/S0431745004025X.

[33] Potato Association of America (PAA) (2018): Potato Varieties. http://potatoassociation.org/industry/varieties. Accessed on 11.03.2019.

[34] Rolbiecki, S., Rzekanowski, Cz., Rolbiecki, R. (2009): Estimation of Needs and Results of Irrigation of Medium-early Potato in the Vicinity of Bydgoszcz in the Years 2005-2007. Acta Agrophysica 13: 463-472. (in Polish).

[35] Tilman, D. (1987): On the Meaning of Competition and the Mecanisms of Competitive Superiority. - Journal of functional Ecology 1: 304-315.

[36] Vollman, J., Wagentristl, H., Hartl, W. (2010): The Effects of Simulated Weed Pressure on Early Maturity Soybeans European. - Journal of Agronomy 32: 243-248. DOI: 10.1016/j.eja.2010.01.001.

[37] Watson, P. R., Derksen, D. A., Van Acker, R. C. (2006): The Ability of 29 Barely Cultivars to Compete and Weethstand Competition. - Weed Science 54: 783-792.

[38] Worthington, M., Reberg-Horton, C. (2013): Breeding Cereal Crops for Enhanced Weed Suppression: Optimizing Allelopathy and Competitive Ability. - Chemical Ecology 39: 213-231. DOI: 10.1007/s10886-013-0247-6.

[39] Żarski, J. (2011): Trends of Climate Change Indicators of Irrigation Needs in Plants Region of Bydgoszcz. - Infrastructure and Ecology of Rural Areas 5: 29-37. (in Polish). 